\title{
POTENSI PASAR MODERN SYARIAH DALAM PENGEMBANGAN EKONOMI MASYARAKAT KOTA PEKANBARU
}

\section{THE POTENTIAL OF THE SHARIA MODERN MARKET IN THE ECONOMIC DEVELOPMENT OF THE CITY OF PEKANBARU CITY}

\author{
Muhammad Arif ${ }^{1}$, Marina Zulfa ${ }^{2}$, Astri Ayu Purwati ${ }^{3}$ \\ Universitas Islam Riau ${ }^{1,2}$, Institut Bisnis dan Teknologi Pelita Indonesia ${ }^{3}$ \\ muhammadarif@fis.uir.ac.id ${ }^{1}$
}

\begin{abstract}
The development of technology today is very influential in people's daily life in terms of economy, social and lifestyle. The present modern sharia market is one of them to answer the changes in the lifestyle of people in urban areas. The purpose of this study was to determine the potential of the modern Islamic market and to find out the most appropriate strategy for the modern Islamic market in developing the economy of the people of Pekanbaru. Data obtained by distributing questionnaires to 384 respondents. The data analysis technique used SWOT analysis followed by making IFAS and EFAS matrices. Priority strategy analysis uses the Quantitative Strategy Planning Matrix (QSPM). From the results of the SWOT analysis, it is known that strengths are more dominant than weaknesses and opportunities are more dominant than threats. From the results of the IFAS matrix, it is known that there is a total value that has a greater influence than the EFAS matrix value. Based on the IFAS and EFAS matrix, it can be said that the Potential of Modern Sharia Markets in the Community Economic Development of Pekanbaru City is still developing "well" and requires creative innovation. based on QSPM analysis, the first priority strategy that must be carried out is to improve the performance of the modern Islamic market management system, open financial reporting and human resource development. The second priority strategy is to break new ground in sales by creating an online application for the modern Islamic market.
\end{abstract}

Keywords: Islamic Modern Market, SWOT, IFAS and EFAS, QSPM.

\begin{abstract}
ABSTRAK
Perkembangan teknologi saat ini sangat berpengaruh bagi kehidupan sehari-hari masyarakat baik dari segi perekonomian, sosial maupun gaya hidup. Pasar modern syariah hadir adalah salah satunya untuk menjawab dari perubahan gaya hidup masyarakat di perkotaan. Tujuan penelitian ini untuk mengetahui potensi pasar modern syariah dan mengetahui strategi yang paling tepat pasar modern syariah dalam mengembangkan ekonomi masyarakat Pekanbaru. Data didapatkan dengan menyebarkan kuisioner kepada 384 orang responden. Teknik analisis data menggunakan analisis SWOT dilanjutkan dengan membuat matriks IFAS dan EFAS. Analisis strategi prioritas menggunakan Quantitative Strategy Planning Matrix (QSPM). Dari hasil analisis SWOT diketahui bahwa kekuatan lebih dominan daripada kelemahan dan peluang lebih dominan daripada ancaman. Dari hasil matriks IFAS diketahui bahwa terdapat nilai total yang lebih besar pengaruhnya dibandingkan dengan nilai matriks EFAS. Berdasarkan matriks IFAS dan EFAS dapat dikatakan bahwa Potensi Pasar
\end{abstract}


Modern Syariah dalam Pengembangan Ekonomi Masyarakat Kota Pekanbaru masih berkembang dengan"baik" dan memerlukan inovasi yang kreatif. rdasarkan analisis QSPM, strategi prioritas pertama yang harus dilakukan adalah Meningkatkan kinerja system manajemen pasar modern Syariah, laporan keuangan terbuka dan pembinaan sumberdaya manusia. Strategi prioritas kedua adalah Melakukan terobosan baru dalam penjualan dengan membuat aplikasi online untuk pasar Syariah modern.

Kata Kunci : Pasar Modern Syariah, SWOT, IFAS dan EFAS, QSPM.

\section{PENDAHULUAN}

Perkembangan teknologi saat ini sangat berpengaruh bagi kehidupan sehari-hari masyarakat baik dari segi perekonomian, sosial, gaya hidup dan lainnya. Hal ini disebabkan oleh kemajuan teknologi yang berjalan sesuai dengan kemajuan ilmu pengetahuan. Dalam bidang teknologi masyarakat dapat menikmati manfaatnya secara positif yang mempermudahkan setiap kegiatan manusia. Maka dari itu dengan berkembangnya teknologi dapat merubah pola gaya hidup masyarakat yang mulanya dengan hal tradisional merubah kebiasaannya ke modern.

Perubahan gaya hidup ini juga berlaku di dunia pasar yang semakin pesatnya perkembangan pasar-pasar modern disetiap wilayah. Sehingga sebagian masyarakat lebih memilih pasar modern dari pada pasar tradisional untuk melengkapi kebutuhan sehari-harinya. Hal ini disebabkan pengaruh dari sistem pelayanan yang cenderung menyajikan dan menyediakan hal-hal yang praktis, ringkas, dan aktual dan memanjakan konsumen/masyarakat (Jun, 2014).

$$
\text { Begitu juga dengan }
$$

perkembangan perekonomian di indonesia seperti di kota-kota besar yang salah satunya menggunakan prinsip syariah. Maka pasar modern pun mulai berprinsipkan syariah baik dari manajerial, sistem pelayanan, hingga produk yang dijual pun harus halal dan tidak boleh melanggar aturan-aturan syariah yang berlaku. Hal ini berkembang sangat pesat disebabkan banyak para kompetitor menangkap peluang ini dan menyebar kepenjuru wilayah salah satunya di kota Pekanbaru-Riau yang mayoritas Muslim.

Adapun pasar modern syariah yang berkembang dan mulai menjamur di kota Pekanbaru antara lain Madani Mart, 212 Mart, Kita Mart dan lain-lain. Diantaranya saling berkompetisi untuk menjalankan programnya masing-masing. Disamping untuk mendapatkan profit mereka juga memiliki program untuk kemashlahatan umat seperti ruang infak untuk kaum dhuafa dan lain sebagainya.

\section{Menurut Data Badan Pusat} Statistik tahun 2016, kota Pekanbaru terdiri dari 12 kecamatan dan 83 Desa/Kelurahan yang merupakan kota multikultur dan juga kota perdagangan, persinggahan, yang berbeda dengan daerah lain karena penduduknya bersifat majemuk dan budaya yang berbeda yang terdiri dari berbagai macam suku diantaranya suku melayu, minang kabau, jawa, batak, dan suku tionghoa. Berbagai budaya ini hidup berdampingan dan keberagaman yang inilah yang menjadi modal sosial dalam mencapai kepentingan bersama.

Pasar modern syariah belakangan ini menjadi salah satu pasar masyarakat kota Pekanbaru untuk memenuhi kebutuhan pribadinya maupun rumah tangganya. Karena pasar jenis ini memiliki waktu yang panjang dan jangkauan yang mudah dan ada dimanamana membuat masyarakat bebas untuk berbelanja kebutuhannya kapanpun dan dimanapun ia inginkan. Pasar modern 
yang dimaksud adalah berbentuk supermarket/swalayan yang menjual kebutuhan pokok seperti barang kebutuhan sehari-hari (Safitri, 2018).

Potensi adalah kemampuan yang mempunyai kekuatan untuk dikembangakan melalui usahausaha terencana dan terprogram melalui strategi-strategi perencanaan yang tepat agar memperoleh hasil yang maksimal yang sesuai ditargetkan.

Menurut Ardhiansyah et.al (2014) potensi adalah kemampuan dari diri seseorang ataupun yang berhubungan dengan hal-hal lain yang dapat digali bahkan dikembangkan.

Berdasakan kedua definisi potensi diatas dapat disimpulkan bahwa potensi merupakan suatu kemampuan yang berhubungan dengan sesuatu objek yang mempunyai kekuatan, yang dapat digali untuk lebih dikembangkan melalui strategi-strategi yang telah terencana untuk mencapai hasil yang maksimal sesuai yang telah ditargetkan.

$\begin{array}{ccc} & \text { Pasar modern } & \text { syariah adalah } \\ \text { pasar } & \text { yang } & \text { pengelolaannya }\end{array}$ menggunakan manajemen modern dan bernuansa Islami, sebagai penyedia barang dan jasa yang bermutu dan halal serta pelayanan yang baik sesuai ketentuan syariah Islam (Mukhtari, 2018).

Ekonomi masyarakat adalah sistem ekonomi yang berbasis pada kekuatan ekonomi masyarakat. Dimana ekonomi masyarakat sendiri adalah sebagian kegiatan ekonomi atau usaha yang dilakukan masyarakat kebanyakan yang dengan cara swadaya mengelola sumber daya ekonomi apa saja yang dapat diusahakan, yang selanjutnya disebut sebagai usaha kecil dan menengah (UKM) terutama meliputi sektor pertanian, perkebunan, peternakan, kerajinan, makanan dan sebagainya. Tujuan dari perekonomian adalah untuk mensejahterakan dan memenuhi kebutuhan hidup masyarakat, serta mencapai kemudahan dan kepuasan. Dengan terpenuhinya kebutuhan masyarakat maka akan tercipta kesejahteraan kelangsungan hidup yang produktif (Mukhtari, 2018).

Analisis SWOT adalah singkatan dari strenghts (kekuatan), weaknesses (kelemahan), opportunity (peluang), threats (ancaman) dimana SWOT ini dijadikan sebagai suatu model dalam menganalisis suatu tujuan utama yang berorientasi profit dan non profit dengan tujuan utama untuk mengetahui keadaan tersebut secara konferensif. (Rusby \& Arif, 2020).

Kekuatan (strenghts) faktorfaktor kekuatan yang dimiliki oleh suatu organisasi, seperti keterampilan, produk dan sebagainya yang membuat lebih kuat dalam memuaskan kebutuhan masyarakat. Kelemahan (weaknesess) merupakan kelemahan yang terdapat dalam tubuh suatu organisasi, seperti kelemahan dalam hal sumber daya, keterampilan kemampuan yang menjadi penghalang serius bagi penampilan kinerja organisasi yang memuaskan. Peluang (opportunity) merupakan berbagai situasi lingkungan yang mengguntungkan bagi suatu bisnis. Ancaman (threats) merupakan faktorfaktor yang tidak menguntungkan (Zaibah, 2015).

\section{METODE PENELITIAN}

Jenis penelitian ini adalah penelitian deskriptif yaitu jenis penelitian yang disusun dalam rangka memberikan gambaran secara sistematis tentang informasi ilmiah yang berasal dari subjek atau objek penelitian.

Adapun yang menjadi subjek penelitian ini adalah minimarket syariah seperti 212 Mart, KitaMart, dan Muslim Madani Mart yang ada di Kota Pekanbaru Sedangkan yang menjadi objek penelitiannya adalah potensi Pasar 
Modern Syariah yang ada di Kota Pekanbaru

Adapun sebagai populasi pada penelitian ini adalah masyarakat Kota Pekanbaru tahun 2020 yang berjumlah 1.117.359 orang

Dari jumlah diatas, maka penulis akan melakukan pengambilan sampel. Adapun jumlah sampel ditentukan berdasarkan rumus Krejcie-Morgan, sebagai berikut :

$$
n=\frac{X^{2} N P(1-P)}{d^{2}(N-1)+X^{2} P(1-P)}
$$

Keterangan :

$\mathrm{n}=$ ukuran sample

$\mathrm{N}=$ ukuran populasi

$\mathrm{P}=$ proporsi populasi $(0,5)$

$\mathrm{d}=$ derajat ketelitian $(0.05)$

$\mathrm{X} 2=$ nilai Tabel X2 $=3,84$

Jika populasinya 1.117.359 maka ukuran sampel yang diperlukan adalah:

$$
\begin{aligned}
n & =\frac{(3.84)(1.117 .359)(0.5)(1-0.5)}{(0.05)^{2}(1.117 .359)+(3.84)(0.5)(1-0.5)} \\
n & =383,86 \approx 384
\end{aligned}
$$

Jadi dalam penelitian ini ukuran sampel jika dibulatkan adalah sebanyak 384 orang. Dan teknik pengambilan sampel dalam penelitian ini adalah Sample Random Sampling, yaitu pengambilan sample secara acak dimana anggota samplenya mendapatkan kesempatan yang sama untuk dijadikan sample.

$$
n=\frac{N i}{N} \times n
$$

Keterangan : $\mathrm{ni}=$ jumlah sampel menurut stratum

$\mathrm{n}=$ jumlah sampel seluruhnya

$\mathrm{Ni}=$ jumlah populasi menurut stratum

$\mathrm{N}=$ jumlah populasi seluruhnya

1. Kecamatan Tampan

$307.947 / 1.117 .359$ × $384=105,83 \approx$ 106

2. Kecamatan Payung Sekaki $91.255 / 1.117 .359 \times 384=31,36 \approx 31$

3. Kecamatan Bukit Raya $105.177 / 1.117 .359$ × $384=36,14 \approx 36$

4. Kecamatan Marpoyan Damai $131.550 / 1.117 .359 \times 384=45.20 \approx 45$

5. Kecamatan Tenayan Raya $167.929 / 1.117 .359$ x $384=57,71 \approx 58$

6. Kecamatan Lima Puluh $41.466 / 1.117 .359 \times 384=14,25 \approx 14$

7. Kecamatan Sail 21.492/1.117.359 x 384=7,38 7

8. Kecamatan Pekanbaru Kota $25.103 / 1.117 .359 \times 384=8,62 \approx 9$

9. Kecamatan Sukajadi $47.420 / 1.117 .359 \times 384=16.29 \approx 16$

10. Kecamatan Senapelan $36.581 / 1.117 .359 \times 384=12,57 \approx 13$

11. Kecamatan Rumbai $67.654 / 1.117 .359 \times 384=23,25 \approx 23$

12. Kecamatan Rumbai Pesisir $73.784 / 1.117 .359 \times 383,9=25,35 \approx 25$

\section{HASIL DAN PEMBAHASAN} Perumusan matriks IFAS DAN EFAS Pembobotan dan Pemberian Rating

Untuk pembobotan dan pemberian rating digunakan untuk mengetahui nilai IFAS dan EFAS yang nanti akan

\begin{tabular}{|c|c|c|c|c|c|c|c|}
\hline No & \multicolumn{2}{|l|}{ Indikator } & Jumlah & Bobot & Bobot Item & Rating & $\begin{array}{c}\text { Bobot Item } \mathrm{X} \\
\text { Rating }\end{array}$ \\
\hline 1 & $\begin{array}{l}\text { Tersedianya Pasar } \\
\text { Syariah } \\
\text { mart/Kitamart/Madani } \\
\text { yang baik }\end{array}$ & $\begin{array}{r}\text { Modern } \\
(212 \\
\text { Mart })\end{array}$ & 1552 & 4.04 & 0.0882 & 4 & 0.3528 \\
\hline 2 & $\begin{array}{l}\text { Tersedianya baran } \\
\text { kebutuhan harian yang } \\
\text { di pasar modern syariah }\end{array}$ & $\begin{array}{l}\text { g-barang } \\
\text { lengkap }\end{array}$ & 1552 & 4.04 & 0.0882 & 3 & 0.2646 \\
\hline
\end{tabular}
digunakan untuk melihat potensi menggunakan matrix IE.

Tabel 1 Indikator Bobot Kekuatan 


\begin{tabular}{|c|c|c|c|c|c|c|}
\hline No & Indikator & Jumlah & Bobot & Bobot Item & Rating & $\begin{array}{c}\text { Bobot Item X } \\
\text { Rating }\end{array}$ \\
\hline 3 & $\begin{array}{l}\text { Akses Pasar Modern } \\
(212 \text { Mart/Kitamart) } \\
\text { mudah } \\
\text { dikunjungi masyarakat. }\end{array}$ & 1532 & 3.99 & 0.0871 & 4 & 0.3483 \\
\hline 4 & $\begin{array}{l}\text { Barang-barang yang dijual di } \\
\text { pasar modern syariah terjamin } \\
\text { kehalalannya dan adanya } \\
\text { dukungan ulama/DSN/Tokoh } \\
\text { Masyarakat. }\end{array}$ & 1545 & 4.02 & 0.0878 & 3 & 0.2634 \\
\hline 5 & $\begin{array}{lr}\text { Konsep berjamaah } & \text { yang } \\
\text { diterapkan koperasi } & \text { syariah } \\
\text { untuk membuka Pasar } & \text { Modern } \\
\text { Syariah } & (212 \\
\text { Mart/Kitamart/Madani Mart })\end{array}$ & 1540 & 4.01 & 0.0875 & 4 & 0.3501 \\
\hline 6 & $\begin{array}{l}\text { Harga saham per lembar pasar } \\
\text { modern syariah relatif } \\
\text { terjangkau oleh masyarakat. }\end{array}$ & 1515 & 3.95 & 0.0861 & 4 & 0.3444 \\
\hline & Rata-rata bobot & \multicolumn{5}{|c|}{4.01} \\
\hline
\end{tabular}

Tabel 2 Indikator Bobot Kelemahan

\begin{tabular}{|c|c|c|c|c|c|c|}
\hline No & Indikator & Jumlah & Bobot & $\begin{array}{l}\text { Bobot } \\
\text { Item }\end{array}$ & Rating & $\begin{array}{l}\text { Bobot Item X } \\
\text { Rating }\end{array}$ \\
\hline 1 & $\begin{array}{l}\text { Harga barang yang relatif lebih } \\
\text { tinggi di pasar modern syariah } \\
\text { dibandingkan dengan harga barang } \\
\text { di pasar modern konvensional. }\end{array}$ & 1425 & 3.71 & 0.0810 & 3 & 0.2430 \\
\hline 2 & $\begin{array}{l}\text { Hurangnya sosialisasi/promosi yang } \\
\text { dilakukan oleh pasar modern } \\
\text { syariah }\end{array}$ & 1346 & 3.51 & 0.0765 & 2 & 0.1530 \\
\hline 3 & $\begin{array}{l}\text { Terbatasnya jumlah outlet pasar } \\
\text { modern syariah di Pekanbaru }\end{array}$ & 1495 & 3.89 & 0.0850 & 3 & 0.2549 \\
\hline 4 & $\begin{array}{l}\text { Belum tersedianya fasilitas } \\
\text { pembayaran (payment) mitra seperti } \\
\text { adira finance, bukalapak, atm, dll } \\
\text { serta belum Tersedianya pasar } \\
\text { modern syariah yang beroperasi } 24 \\
\text { jam. }\end{array}$ & 1412 & 3.68 & 0.0802 & 2 & 0.1605 \\
\hline 5 & $\begin{array}{l}\text { Terbatasnya jenis-jenis produk yang } \\
\text { dijual di pasar modern syariah }\end{array}$ & 1362 & 3.55 & 0.0774 & 3 & 0.2322 \\
\hline 6 & $\begin{array}{l}\text { Tersedianya potongan harga } \\
\text { (discount) bagi masyarakat di pasar } \\
\text { modern syariah. }\end{array}$ & 1320 & 3.44 & 0.0750 & 3 & 0.2251 \\
\hline & Rata-rata bobot & \multicolumn{5}{|c|}{3.63} \\
\hline
\end{tabular}

Tabel 3 Indikator Bobot Peluang

\begin{tabular}{lllllll}
\hline No & Indikator & Jumlah & Bobot & $\begin{array}{l}\text { Bobot } \\
\text { Item }\end{array}$ & Rating & $\begin{array}{l}\text { Bobot Item X } \\
\text { Rating }\end{array}$ \\
\hline 1 & $\begin{array}{l}\text { Tentang } \\
\text { ekonomi syariah yang } \\
\text { semakin baik }\end{array}$ & 1539 & 4.01 & 0.0893 & 3 & 0.2679 \\
\hline 2 & $\begin{array}{l}\text { Banyaknya } \\
\text { kajian/seminar tentang halal }\end{array}$ & 1539 & 4.01 & 0.0893 & 4 & 0.3572 \\
\hline
\end{tabular}




\begin{tabular}{|c|c|c|c|c|c|c|}
\hline No & Indikator & Jumlah & Bobot & $\begin{array}{l}\text { Bobot } \\
\text { Item } \\
\end{array}$ & Rating & $\begin{array}{l}\text { Bobot Item X } \\
\text { Rating }\end{array}$ \\
\hline & industri di Pekanbaru & & & & & \\
\hline 3 & $\begin{array}{l}\text { Budaya Melayu yang kental } \\
\& \text { Mayoritas penduduk } \\
\text { Pekanbaru beragama Islam }\end{array}$ & 1522 & 3.96 & 0.0883 & 3 & 0.2649 \\
\hline 4 & $\begin{array}{l}\text { Adanya kebijakan dan upaya } \\
\text { pemerintah untuk mendorong } \\
\text { ekonomi syariah }\end{array}$ & 1529 & 3.98 & 0.0887 & 4 & 0.3549 \\
\hline 5 & $\begin{array}{l}\text { Komitmen pemerintah daerah } \\
\text { dalam pemberian izin usaha }\end{array}$ & 1525 & 3.97 & 0.0885 & 4 & 0.3540 \\
\hline 6 & $\begin{array}{l}\text { Tingginya minat wirausaha } \\
\text { masyarakat di Pekanbaru. }\end{array}$ & 1540 & 4.01 & 0.0894 & 4 & 0.3574 \\
\hline
\end{tabular}

Tabel 4 Indikator Bobot Ancaman

\begin{tabular}{|c|c|c|c|c|c|c|}
\hline No & Indikator & Jumlah & Bobot & Bobot Item & Rating & $\begin{array}{c}\text { Bobot Item X } \\
\text { Rating } \\
\end{array}$ \\
\hline 1 & $\begin{array}{l}\text { Kurangnya pengetahuan } \\
\text { masyarakat tentang } \\
\text { pentingnya produk halal. }\end{array}$ & 1323 & 3.45 & 0.0768 & 2 & 0.1535 \\
\hline 2 & $\begin{array}{l}\text { Kebiasaan masyarakat } \\
\text { berbelanja } \\
\text { supermarket } \\
\text { konvensional. }\end{array}$ & 1397 & 3.64 & 0.0811 & 2 & 0.1621 \\
\hline 3 & $\begin{array}{l}\text { Menjamurnya bisnis } \\
\text { waralaba konvensional } \\
\text { di kota Pekanbaru } \\
\text { (Indomaret, alfamart, } \\
\text { giant, planet swalayan, } \\
\text { dll). }\end{array}$ & 1299 & 3.38 & 0.0754 & 2 & 0.1507 \\
\hline 4 & $\begin{array}{l}\text { Meningkatnya market } \\
\text { place digital (toko } \\
\text { online) konvensional. }\end{array}$ & 1311 & 3.41 & 0.0761 & 2 & 0.1521 \\
\hline 5 & $\begin{array}{l}\text { Adanya toko grosir yang } \\
\text { menawarkan dengan } \\
\text { harga yang relatif } \\
\text { murah. }\end{array}$ & 1380 & 3.59 & 0.0801 & 2 & 0.1601 \\
\hline 6 & $\begin{array}{lr}\text { Adanya } & \text { kerjasama } \\
\text { agen/produsen produk } \\
\text { non halal seperti } & \text { rokok, } \\
\text { minuman keras yang } \\
\text { menjadi r sumber } \\
\text { keuntungan r pasar } \\
\text { modern konvensional. }\end{array}$ & 1330 & 3.46 & 0.0772 & 2 & 0.1543 \\
\hline & Rata-rata bobot & & & 3.49 & & \\
\hline
\end{tabular}

\section{Matriks IFAS}

Untuk mengatahui hasil dari indikator kekuatan dan kelemahan dilihat dari bobot item dikali dengan rating dan melihat hasil total akhir untuk penentuan di matriks IE. Dan hasil total dari bobot item dikali dengan item dengan total 3,26 $\begin{array}{ccr}\text { Hasil dan } & \begin{array}{c}\text { pembahasan } \\ \text { dengan }\end{array} \\ \text { disesuaikan } & \text { penatan }\end{array}$ penelitian. Jika pendekatan penelitian kuantitatif terdiri dari statistika deskriptif, hasil uji asumsi dan hasil uji hipotesis kemudian dianalisis secara kritis. Jika pendekatan kualitatif berupa tema-tema 
hasil analisis kualitatif yang dilakukan.

pustaka, berupa pernyataan naratif.

Jika gagasan konseptual dan studi

Tabel 5 Matriks IFAS

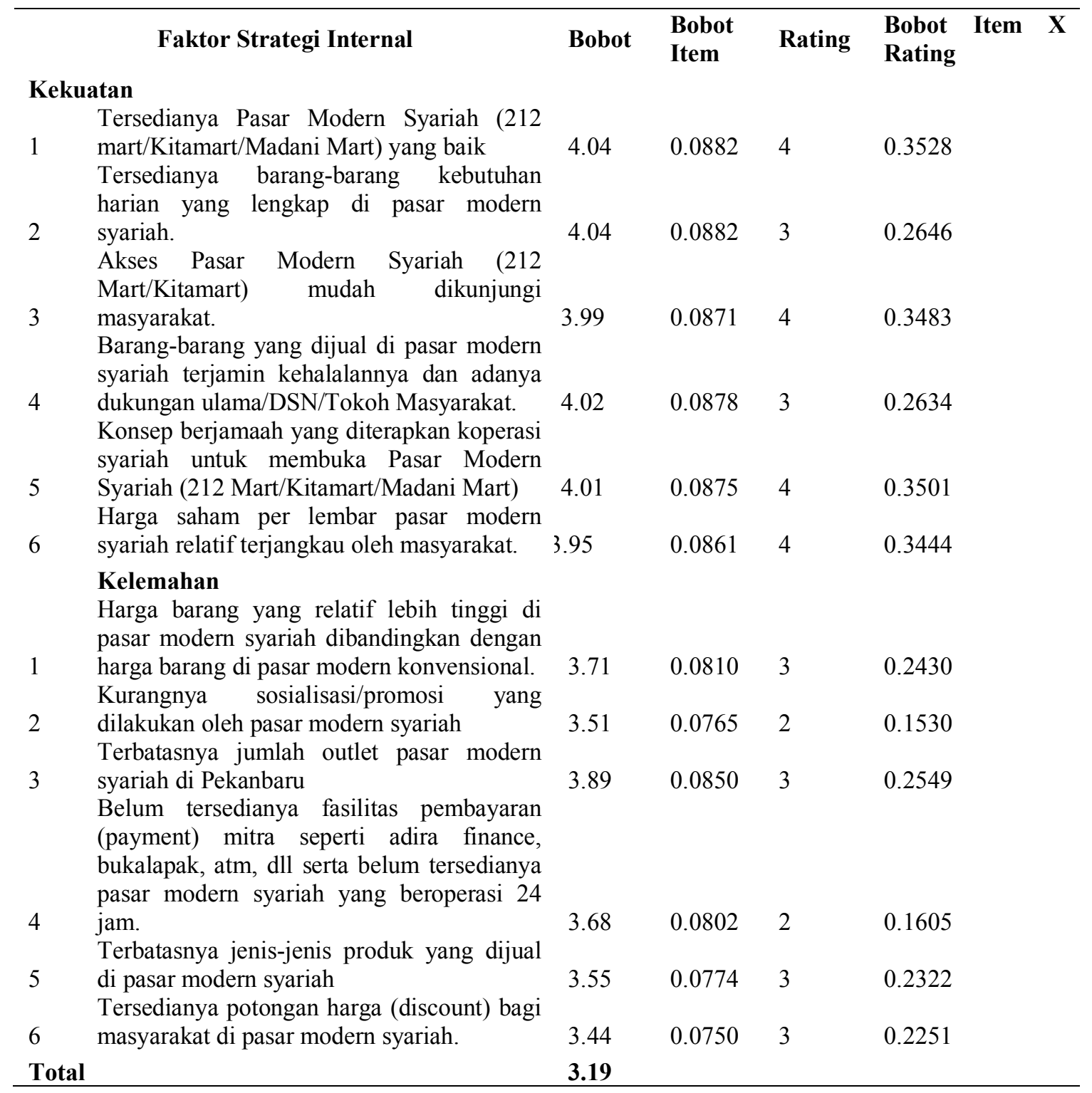

Matriks EFAS

Untuk mengetahui hasil dari indikator Peluang dan Ancaman yang dilihat dari bobot item dikali dengan rating dan untuk melihat hasil total akhir untuk penentuan di matriks IE. Dan hasil dari bobot item dikali dengan rating yaitu dengan jumlah total 2,84 .

Tabel 6 Matriks EFAS

\begin{tabular}{|c|c|c|c|c|c|}
\hline & Faktor Strategi Eksternal & Bobot & $\begin{array}{l}\text { Bobot } \\
\text { Item }\end{array}$ & Rating & $\begin{array}{l}\text { Bobot Item X } \\
\text { Rating }\end{array}$ \\
\hline \multicolumn{6}{|c|}{ Peluang } \\
\hline 1 & $\begin{array}{l}\text { Tentang perkembangan ekonomi syariah } \\
\text { yang semakin baik }\end{array}$ & 4.01 & 0.0893 & 3 & 0.2679 \\
\hline
\end{tabular}




\begin{tabular}{llllll}
\hline \multicolumn{1}{c}{ Faktor Strategi Eksternal } & Bobot & $\begin{array}{l}\text { Bobot } \\
\text { Item }\end{array}$ & Rating & $\begin{array}{l}\text { Bobot Item X } \\
\text { Rating }\end{array}$ \\
\hline 2 & $\begin{array}{l}\text { Banyaknya kajian-kajian/seminar tentang } \\
\text { halal industri di Pekanbaru }\end{array}$ & 4.01 & 0.0893 & 4 & 0.3572 \\
\hline 3 & $\begin{array}{l}\text { Budaya Melayu yang kental \& Mayoritas } \\
\text { penduduk Pekanbaru beragama Islam }\end{array}$ & 3.96 & 0.0883 & 3 & 0.2649 \\
\hline $\begin{array}{l}\text { Adanya kebijakan dan upaya pemerintah } \\
\text { untuk mendorong ekonomi syariah }\end{array}$ & 3.98 & 0.0887 & 4 & 0.3549 \\
\hline $5 \quad \begin{array}{l}\text { Komitmen pemerintah daerah dalam } \\
\text { pemberian izin usaha }\end{array}$ & 3.97 & 0.0885 & 4 & 0.3540 \\
\hline $\begin{array}{l}\text { Tingginya minat wirausaha masyarakat di } \\
\text { Pekanbaru. }\end{array}$ & 4.01 & 0.0894 & 4 & 0.3574 \\
\hline Ancaman & $\begin{array}{l}\text { Kurangnya pengetahuan masyarakat tentang } \\
\text { pentingnya produk halal. }\end{array}$ & 3.45 & 0.0768 & 2 & 0.1535 \\
\hline $\begin{array}{l}\text { Kebiasaan masyarakat berbelanja di } \\
\text { supermarket konvensional. }\end{array}$ & 3.64 & 0.0811 & 2 & 0.1621 \\
\hline $\begin{array}{l}\text { Menjamurnya bisnis waralaba konvensional } \\
\text { di kota Pekanbaru (Indomaret, alfamart, } \\
\text { giant, planet swalayan, dll). }\end{array}$ & 3.38 & 0.0754 & 2 & 0.1507 \\
\hline $\begin{array}{l}\text { Meningkatnya market place digital (toko } \\
\text { online) konvensional. }\end{array}$ & 3.41 & 0.0761 & 2 & 0.1521 \\
\hline $\begin{array}{l}\text { Adanya toko grosir yang menawarkan } \\
\text { dengan harga yang relatif murah. }\end{array}$ & 3.59 & 0.0801 & 2 & 0.1601 \\
\hline $\begin{array}{l}\text { Adanya kerjasama agen/produsen produk } \\
\text { non halal seperti rokok, minuman keras yang } \\
\text { menjadi sumber keuntungan pasar modern } \\
\text { konvensional. }\end{array}$ & & & \\
\hline Total & 3.46 & 0.0772 & 2 & 0.1543 \\
\hline
\end{tabular}

Pencocokan matrik SWOT dan matrik IE

Berdasarkan keterangan pada tabel internal faktor Strategi/tabel eksternal faktor strategi (IFAS/EFAS) tersebut maka dapat dijabarkan sebagai berikut.

Tabel 7 Matriks SWOT

\begin{tabular}{|c|c|c|}
\hline Faktor Internal & 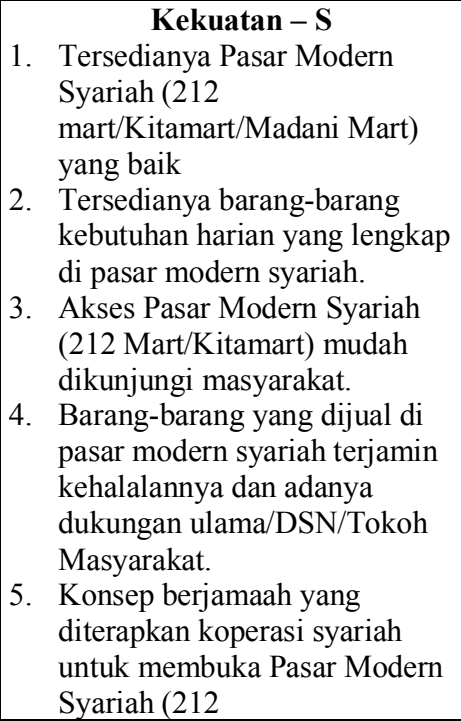 & $\begin{array}{l}\text { Kelemahan - W } \\
\text { 1. Harga barang yang relatif lebih } \\
\text { tinggi di pasar modern syariah } \\
\text { dibandingkan dengan harga } \\
\text { barang di pasar modern } \\
\text { konvensional. } \\
\text { 2. Kurangnya sosialisasi/promosi } \\
\text { yang dilakukan oleh pasar } \\
\text { modern syariah } \\
\text { 3. Terbatasnya jumlah outlet } \\
\text { pasar modern syariah di } \\
\text { Pekanbaru } \\
\text { 4. Belum tersedianya fasilitas } \\
\text { pembayaran (payment) mitra } \\
\text { seperti adira finance, } \\
\text { bukalapak, atm, dll serta belum } \\
\text { tersedianya pasar modern } \\
\text { syariah yang beroperasi } 24 \\
\text { jam. } \\
\text { 5. Terbatasnya jenis-jenis produk }\end{array}$ \\
\hline
\end{tabular}




\begin{tabular}{|c|c|c|}
\hline & $\begin{array}{l}\text { Mart/Kitamart/Madani Mart) } \\
\text { 6. Harga saham per lembar pasar } \\
\text { modern syariah relatif } \\
\text { terjangkau oleh masyarakat. }\end{array}$ & $\begin{array}{l}\text { yang dijual di pasar modern } \\
\text { syariah } \\
\text { 6. Tersedianya potongan harga } \\
\text { (discount) bagi masyarakat di } \\
\text { pasar modern syariah. }\end{array}$ \\
\hline 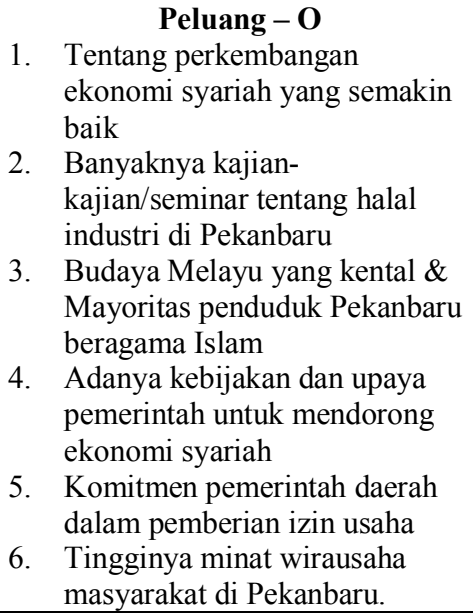 & \begin{tabular}{l}
\multicolumn{1}{c}{ SO - Strategi } \\
1. Meningkatkan kinerja system \\
manajemen pasar modern \\
Syariah, laporan keuangan \\
terbuka dan pembinaan \\
sumberdaya manusia
\end{tabular} & $\begin{array}{l}\text { WO - Strategi } \\
\text { 1. Melakukan terobosan baru } \\
\text { dalam penjualan dengan } \\
\text { membuat aplikasi online } \\
\text { untuk pasar Syariah modern }\end{array}$ \\
\hline 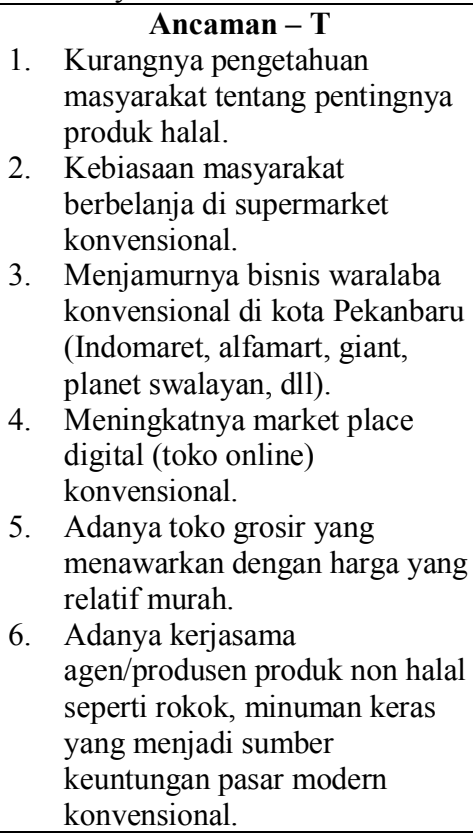 & $\begin{array}{c}\text { ST }- \text { Strategi } \\
\text { 1. } \\
\text { Melakukan kampanye untuk } \\
\text { belanja di pasar Syariah } \\
\text { modern dengan konsisten } \\
\text { baik di media social, kajian } \\
\text { maupun media cetak }\end{array}$ & $\begin{array}{l}\text { WT - Strategi } \\
\text { 1. Membeli barang langsung dari } \\
\text { produsen atau petani sehingga } \\
\text { mendapatkan harga pokok } \\
\text { lebih murah }\end{array}$ \\
\hline
\end{tabular}

Sumber : Data Olahan, 2020

Matriks IE ( IFAS DAN EFAS )

Matriks IE adalah penentuan hasil total dari matriks IFAS dan EFAS yang menentukan nilai berpotensi atau tidaknya dari hasil nilai total tabel IFAS dan EFAS.

Tabel 8 Matriks IE

\begin{tabular}{lrrrrr}
\hline & kuat & rata-rata & lemah & \\
\hline & & 4.0 & 3.0 & 2.0 & 1.0 \\
\hline $\begin{array}{l}\text { Tabel } \\
\text { nilai }\end{array}$ & & Sel I & Sel II & Sel IiI & \\
EFAS & & & & & \\
\hline
\end{tabular}




\begin{tabular}{lllll}
\hline \multirow{2}{*}{ sedang } & & Sel IV & Sel V & Sel VI \\
& & & \\
\hline 2.0 & & & \\
\hline & Sel VII & Sel VIII & Sel IX
\end{tabular}

rendah

Matrik IE diatas menunjukan bahwa berdasarkan total bobot nilai IFAS adalah 3,19 dan bobot nilai EFAS adalah 2,89. Sehingga jika di tarik sumbu $X$ (IFAS) dan sumbu Y (IFAS) maka potensi usaha travel haji dan umrah di Provinsi Riau berada pada sel 4. Artinya Potensi Pasar Modern Syariah dalam Pengembangan Ekonomi Masyarakat Kota Pekanbaru dalam kategori "BAIK" namun perlu usaha lebih keras lagi dalam pengembangannya. Dan perlu pengembangan dan inovasi Pasar Modern Syariah dalam Pengembangan Ekonomi Masyarakat Kota Pekanbaru.

Analisis Quantitative Strategic Planning Matrix (QSPM)

Tahap akhir setelah tahap pencocokan yaitu tahap keputusan. Pada tahap ini, dapat dilakukan pemilihan strategi dengan cara memeringkat strategi dalam skala 1 sampai dengan 4 , dengan demikian daftar prioritas dari strategi terbaik dapat dihasilkan.

Tabel 9 Analisis Quantitative Strategic Planning Matrix (QSPM)

\begin{tabular}{llllllllll}
\hline \multirow{2}{*}{$\begin{array}{l}\text { Faktor } \\
\text { Strategis }\end{array}$} & \multirow{2}{*}{ Bobot } & \multicolumn{2}{l}{ Strategi 1 } & \multicolumn{3}{l}{ Strategi 2 } & \multicolumn{2}{l}{ Strategi 3 } & \multicolumn{2}{l}{ Strategi 4 } \\
\cline { 3 - 10 } & & AS & TAS & AS & TAS & AS & TAS & AS & TAS \\
\hline S1 & 0.0882 & 4 & 0.3528 & 4 & 0.3528 & 3 & 0.2646 & 2 & 0.1764 \\
S2 & 0.0882 & 3 & 0.2646 & 4 & 0.3528 & 4 & 0.3528 & 4 & 0.3528 \\
S3 & 0.0871 & 4 & 0.3483 & 4 & 0.3483 & 3 & 0.2612 & 4 & 0.3483 \\
S4 & 0.0878 & 3 & 0.2634 & 2 & 0.1756 & 4 & 0.3512 & 2 & 0.1756 \\
S5 & 0.0875 & 4 & 0.3501 & 2 & 0.1750 & 3 & 0.2626 & 4 & 0.3501 \\
S6 & 0.0861 & 4 & 0.3444 & 4 & 0.3444 & 3 & 0.2583 & 4 & 0.3444 \\
W1 & 0.0810 & 3 & 0.2430 & 3 & 0.2430 & 4 & 0.3239 & 2 & 0.1620 \\
W2 & 0.0765 & 2 & 0.1530 & 2 & 0.1530 & 2 & 0.1530 & 2 & 0.1530 \\
W3 & 0.0850 & 3 & 0.2549 & 3 & 0.2549 & 2 & 0.1699 & 2 & 0.1699 \\
W4 & 0.0802 & 2 & 0.1605 & 2 & 0.1605 & 3 & 0.2407 & 2 & 0.1605 \\
W5 & 0.0774 & 3 & 0.2322 & 3 & 0.2322 & 2 & 0.1548 & 2 & 0.1548 \\
W6 & 0.0750 & 3 & 0.2251 & 3 & 0.2251 & 3 & 0.2251 & 2 & 0.1500 \\
\hline & 1.00 & & & & & & & & \\
\hline O1 & 0.0893 & 3 & 0.2679 & 3 & 0.2679 & 3 & 0.2679 & 3 & 0.2679 \\
O2 & 0.0893 & 4 & 0.3572 & 2 & 0.1786 & 4 & 0.3572 & 2 & 0.1786 \\
O3 & 0.0883 & 4 & 0.3533 & 4 & 0.3533 & 2 & 0.1766 & 4 & 0.3533 \\
O4 & 0.0887 & 4 & 0.3549 & 3 & 0.2662 & 3 & 0.2662 & 3 & 0.2662 \\
O5 & 0.0885 & 4 & 0.3540 & 2 & 0.1770 & 4 & 0.3540 & 2 & 0.1770 \\
O6 & 0.0894 & 2 & 0.1787 & 4 & 0.3574 & 2 & 0.1787 & 4 & 0.3574
\end{tabular}




\begin{tabular}{llllllllll}
\hline \multirow{2}{*}{$\begin{array}{l}\text { Faktor } \\
\text { Strategis }\end{array}$} & \multirow{2}{*}{ Bobot } & \multicolumn{2}{c}{ Strategi 1 } & \multicolumn{3}{c}{ Strategi 2 } & \multicolumn{2}{c}{ Strategi 3 } & \multicolumn{2}{c}{ Strategi 4 } \\
\cline { 2 - 10 } & & AS & TAS & AS & TAS & AS & TAS & AS & TAS \\
\hline T1 & 0.0768 & 2 & 0.1535 & 4 & 0.3071 & 3 & 0.2303 & 2 & 0.1535 \\
T2 & 0.0811 & 2 & 0.1621 & 4 & 0.3242 & 4 & 0.3242 & 3 & 0.2432 \\
T3 & 0.0754 & 2 & 0.1507 & 3 & 0.2261 & 2 & 0.1507 & 3 & 0.2261 \\
T4 & 0.0761 & 2 & 0.1521 & 4 & 0.3043 & 3 & 0.2282 & 2 & 0.1521 \\
T5 & 0.0801 & 2 & 0.1601 & 4 & 0.3203 & 4 & 0.3203 & 3 & 0.2402 \\
T6 & 0.0772 & 2 & 0.1543 & 3 & 0.2315 & 2 & 0.1543 & 3 & 0.2315 \\
\hline & 1.00 & & 5.0672 & & 5.0180 & & 4.9441 & & 4.6161 \\
\hline
\end{tabular}

Sumber : Data Olahan, 2020

Tahapan terakhir dalam analisis Potensi Pasar Modern Syariah dalam Pengembangan Ekonomi Masyarakat Kota Pekanbaru adalah pemilihan strategi yang sesuai dan dapat dijalankan oleh pihak perusahaan. Alat analisis yang digunakan dalam penentuan strategi adalah dengan Quantitative Strategy Planning Matrix (QSPM). Tahap terakhir ini merupakan tahap penyusunan QSPM yang akan menghasilkan urutan prioritas strategi yang diusulkan, berdasarkan dari hasil Matriks SWOT sebelumnya.

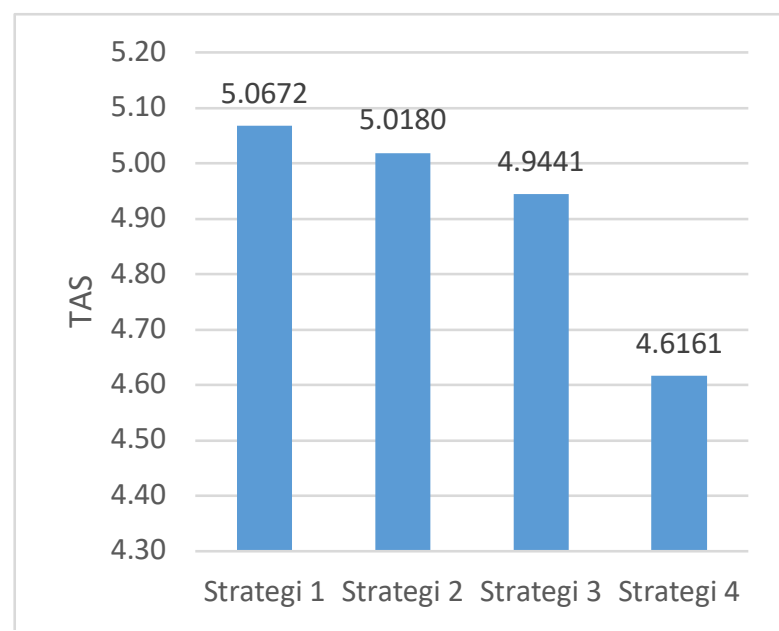

Gambar 1 Analisis Quantitative Strategy Planning Matrix (QSPM)

Hasil kuesioner tentang pemilihan alternatif strategi menunjukkan tentang alternatif strategi yang paling diminati oleh responden. Alternatif strategi dengan nilai Sum Total Atractiveness Score (STAS) tertinggi merupakan strategi yang menjadi prioritas utama bagi perusahaan. Berdasarkan hasil analisis dengan menggunakan Matriks QSPM, diperoleh tingkat prioritas Potensi Pasar Modern Syariah dalam Pengembangan Ekonomi Masyarakat Kota Pekanbaru yaitu :
1. Meningkatkan kinerja system manajemen pasar modern Syariah, laporan keuangan terbuka dan pembinaan sumberdaya manusia. Strategi ini mendapatkan nilai TAS 5.0672 .

2. Melakukan terobosan baru dalam penjualan dengan membuat aplikasi online untuk pasar Syariah modern. Strategi ini mendapatkan nilai TAS 5.0180 .

3. Melakukan kampanye untuk belanja di pasar Syariah modern dengan 
konsisten baik di media social, kajian maupun media cetak. Strategi ini mendapatkan nilai TAS 4.9441.

Membeli barang langsung dari produsen atau petani sehingga mendapatkan harga pokok lebih murah Memperkuat jaringan dan mempermudah layanan kepada pelanggan dan tim marketing di daerah dengan system online. Nilai TAS.

Pasar Penelitian ini tentang Potensi Pengembangan Ekonomi Masyarakat Kota Pekanbaru. Analisis data yang digunakan dalam penelitian ini adalah analisis kualitatif yang digunakan untuk menganalisis secara gambaran umum tentang latar belakang penelitian sebagai bahan penelitian dan dengan menggunakan metode analisis SWOT dan menggunakan matriks SWOT, matriks IFAS dan Matriks EFAS dan matriks IE.

Pada penelitian ini terdapat konsep operasional analisis SWOT yang terdiri dari faktor Kekuatan, Kelemahan, Ancaman, dan Peluang. Yang memiliki pengaruh kepada faktor indikator potensi pengembangan Potensi Pasar Modern Syariah dalam Pengembangan Ekonomi Masyarakat Kota Pekanbaru, keempat indikator dari konsep operasional analisis SWOT. Merupakan gambaran dari hasil analisis SWOT Potensi Pasar Modern Syariah dalam Pengembangan Ekonomi Masyarakat Kota Pekanbaru.

Pasar Modern Syariah merupakan pasar modern Islami dengan konsep Sharing Economy (Ekonomi Berbagi), konsep yang berbeda dengan minimarket yang sudah ada sebelumnya. Dimana, Pasar Modern Syariah adalah tempat berbelanja yang menjual semua produk dengan terjamin kehalalannya baik dari makanan ringan sampai pada kebutuhan pokok, mereka juga tidak menjual rokok. Pasar Modern Syariah merupakan salah satu usaha yang cukup berkembang dengan sangat cepat sehingga pada saat ini Pasar Modern Syariah banyak memiliki cabang di seluruh wilayah Indonesia, untuk itu pastinya Pasar Modern Syariah tidak lepas dalam melakukan strategi-strategi untuk meningkatkan penjualan khususnya pada strategi pemasaran. Strategi pemasaran merupakan analisis pengambilan keputusan tentang bauran pemasaran yaitu, strategi produk, strategi harga, strategi tempat dan strategi promosi yang dirancang untuk memenuhi keinginan konsumen dan untuk mencapai tujuan pemasaran (Wangko, 2013; Rusby 2014).

Berdasarkan analisis secara analisis SWOT peneliti melakukan penelitian ini maka dapat dijelaskan bahwa ada pengaruh yang positif yang dapat dilihat dari matriks IE, dari keempat indikator SWOT antara indikator kekuatan, kelemahan, peluang, dan ancaman. Hasil analisis mendapatkan Potensi Pasar Modern Syariah dalam Pengembangan Ekonomi Masyarakat Kota Pekanbaru masih bisa berkembang dan baik dan membutuhkan inovasi pelayanan terkini. Ini telah di buktikan dari tabel matriks IFAS dengan nilai total 3,19 dan tabel matriks EFAS dengan nilai total 2,89 .

Penulis juga telah melakukan pengujian antara matriks IFAS dan matriks EFAS merupakan bentuk lain yang digunakan untuk menentukan nilai atau cell di matriks IE untuk mengetahui Potensi Pasar Modern Syariah dalam Pengembangan Ekonomi Masyarakat Kota Pekanbaru. Diketahui bahwa besar nilai total dari tabel IFAS di matriks IE berada di sel 4 dengan nilai 3,19 lebih besar dari pada tabel EFAS di matriks IE berada di sel 4 dengan nilai sebesar 2,89 ini menunjukan bahwa hasil pembobotan terhadap faktor-faktor yang berpengaruh, diperoleh hasil bahwa faktor-faktor internal IFAS (kekuatan dan kelemahan) dengan nilai yaitu 3,196 lebih besar 
pengaruhnya dibandingkan dengan faktor eksternal EFAS (peluang dan ancaman) dengan nilai 2,89 .

Dengan demikian, dari penjelasan secara teori dari hasil penghitungan dengan menggunakan matriks IFAS dan EFAS dengan hasil akhir menggunakan matriks IE memiliki pengaruh yang positif dan siginifikan terhadap pengembangan Potensi Pasar Modern Syariah dalam Pengembangan Ekonomi Masyarakat Kota Pekanbaru (Mukhtari 2018).

Berdasarkan analisis QSPM, strategi prioritas pertama yang harus dilakukan adalah Meningkatkan kinerja system manajemen pasar modern Syariah, laporan keuangan terbuka dan pembinaan sumberdaya manusia. Strategi prioritas kedua adalah Melakukan terobosan baru dalam penjualan dengan membuat aplikasi online untuk pasar Syariah modern

\section{PENUTUP}

\section{Kesimpulan}

Berdasarkan dari hasil pembahasan yang telah diuraikan sebelumnya terkait potensi pasar modern syariah dalam pengembangan ekonomi syariah masyarakat kota Pekanbaru maka penulis dapat menyusun beberapa kesimpulan sebagai berikut :

1 Dari hasil analisis SWOT diketahui bahwa kekuatan lebih dominan daripada kelemahan dan peluang lebih dominan daripada ancaman.

2 Dari hasil matriks IFAS diketahui bahwa terdapat nilai total yang lebih besar pengaruhnya dibandingkan dengan nilai matriks EFAS.

3 Berdasarkan matriks IFAS dan EFAS dapat dikatakan bahwa Potensi Pasar Modern Syariah dalam Pengembangan Ekonomi Masyarakat Kota Pekanbaru masih berkembang dengan"baik" dan memerlukan inovasi yang kreatif.

\section{Saran}

Berdasarkan analisis QSPM, strategi prioritas pertama yang harus dilakukan adalah Meningkatkan kinerja system manajemen pasar modern Syariah, laporan keuangan terbuka dan pembinaan sumberdaya manusia. Strategi prioritas kedua adalah Melakukan terobosan baru dalam penjualan dengan membuat aplikasi online untuk pasar Syariah modern

\section{DAFTAR PUSTAKA}

Ardhiansyah, D. (2014). Analisis Potensi Pajak Hotel dan Pajak Restoran dan Kontribusinya Terhadap Pendapatan Asli Daerah Kota Batu. Jurnal Administrasi Bisnis (JAB), 4(1)

Jun, C. (2014). Perubahan Gaya Hidup Anak Muda di Surakarta Akibat Berkembangnya Mall. Tesis program Studi Kajian Budaya Pascasarjana Universitas Sebelas Maret Surakarta (Doctoral dissertation, UNS (Sebelas Maret University)).

Mukhtari, A. (2018). Analisis kesesuaian produk dan pelayanan hotel berbasis syariah di Riez Palace Hotel Tegal(Doctoral dissertation, UIN Walisongo Semarang).

Rusby, Z \& Muhammad, A. (2020). Development of Sharia Tourism in Riau Province Indonesia. African Journal of Hospitality, Tourism and Leisure, 8 (5).

Rusby, Z. (2014). Pemikiran Ekonomi Dalam Islam. Pekanbaru : Pusat Kajian Pendidikan Islam FAI UIR.

Safitri, Y. (2018). Pengaruh jual beli online terhadap omzet jual beli offline di desa Kelayu Kecamatan Selong Kabupaten Lombok Timur (Doctoral dissertation, Universitas Islam Negeri Mataram). 
Wangko, M., C. (2013). Pengaruh Strategi Bauran Pemasaran Terhadap Keputusan Pembelian Mobil Panther Pada PT Astra Internasional-Izuzu Manado. Jurnal EMBA: Jurnal Riset Ekonomi, Manajemen, Bisnis dan Akuntansi, 1(3).

Zaibah, A. (2015). Analisis SWOT Dalam Pengelolaan Tempat Wisata di Kabupaten Rokan Hulu, Fakultas Sosial Politik, Universitas Islam Riau, Pekanbaru. 